\title{
Corrigendum
}

\section{Dietary supplementation with a specific combination of high protein, leucine, and fish oil improves muscle function and daily activity in tumour-bearing cachectic mice}

\author{
K van Norren, D Kegler, JM Argilés, Y Luiking, M Gorselink, A Laviano, K Arts, J Faber, H Jansen, \\ EM van der Beek and $A$ van Helvoort
}

British Journal of Cancer (2009) I 00, I2II. doi:10.1038/sj.bjc.6605005 www.bjcancer.com

(c) 2009 Cancer Research UK

Correction to: British Journal of Cancer (2009) 99, 713-722. doi: $10.1038 /$ sj.bjc. 6604905

During correction of the above manuscript, the second affiliation of the lead author (Klaske van Norren) was omitted. The full affiliations are now shown below.

K Van Norren ${ }^{\star 1,5}$, D Kegler ${ }^{1}$, JM Argilés $^{2}$, Y Luiking ${ }^{1}$, M Gorselink ${ }^{3}$, A Laviano $^{4}, \mathrm{~K}$ Arts $^{6}$, J Faber ${ }^{1}$, H Jansen ${ }^{1}$, EM van der Beek ${ }^{1}$ and $A$ van Helvoort ${ }^{1}$
${ }^{1}$ Danone Research - Centre for Specialised Nutrition (formerly known as Numico Research), Wageningen, The Netherlands; ${ }^{2}$ Cancer Research Group, Departament de Bioquímica i Biologia Molecular, Facultat de Biologia, Universitat de Barcelona, Spain; ${ }^{3}$ Center for Innovative Consumer Studies, Wageningen UR, The Netherlands; ${ }^{4}$ Department of Clinical Medicine, University La Sapienza, Rome, Italy; ${ }^{5}$ Nutrition and Pharmacology Group, Division of Human Nutrition, Wageningen University, The Netherlands; ${ }^{6}$ Former employee of Numico Research, Danone Research - Centre for Specialised Nutrition (formerly known as Numico Research), Wageningen, The Netherlands 